\title{
The influence of environmental variables on the functional structure of headwater stream fish assemblages: a study of two tropical basins in Central Brazil
}

\author{
Rodrigo Assis Carvalho ${ }^{1,2}$ and Francisco Leonardo Tejerina-Garro ${ }^{2,3,4}$
}

We investigated functional patterns of fish assemblages of two adjacent basins (Araguaia and Tocantins) to test whether their headwater stream fish assemblages are more functionally (dis)similar than expected by chance and whether these (dis)similarities are related to differences of environmental conditions between basins. We used an analysis of similarities (ANOSIM) on a functional dissimilarity matrix to test for (dis)similarities between fish assemblages of both basins. We performed RLQ and fourth-corner analyses to determine fish species trait-environment relationship. Our results revealed functional dissimilarities between fish assemblages of both basins and significant species trait-environment relationships, suggesting that environmental conditions are driving such dissimilarities. Inter-basin dissimilarities are mainly driven by altitudinal and water temperature gradients, whereas dissimilarities among streams within the basins are influenced by channel depth, turbidity and conductivity. These five environmental variables mostly affected six fish species traits (body mass, water column position, substrate preference, parental care, foraging locality and migration) in different manners. This study is an attempt to understand functional trends of fish assemblages in a tropical region that remains poorly known but severely threatened.

Nós investigamos os padrões funcionais das assembleias de peixes de duas bacias adjacentes (Araguaia and Tocantins) para testar se as assembleias de peixes de seus riachos de cabeceira são funcionalmente mais (dis)similares do que o esperado ao acaso e se estas (dis)similaridades estão relacionadas a diferenças nas condições ambientais entre as bacias. Nós utilizamos uma análise de similaridades (ANOSIM) sobre uma matriz de dissimilaridade funcional para testar por (dis)similaridades entre as assembleias de peixes das duas bacias. Nós realizamos análises de RLQ e fourth-corner para determinar a relação entre o ambiente e a estrutura funcional das assembleias de peixes. Nossos resultados revelaram dissimilaridades funcionais entre as assembleias de peixes de ambas as bacias e relações significativas entre atributos das espécies e o ambiente, sugerindo que as condições ambientais estão direcionando tais dissimilaridades. As dissimilaridades entre bacias são influenciadas principalmente pelos gradientes de altitude e temperatura da água, enquanto as dissimilaridades entre os riachos na bacia pela profundidade do canal, turbidez e condutividade. Estas cinco variáveis ambientais afetaram principalmente seis atributos das espécies de peixes (massa corporal, posição na coluna de água, preferência por substrato, cuidado parental, local de forrageio e migração) de diferentes maneiras. Este estudo é uma tentativa para entender os padrões funcionais das assembleias de peixes de uma região ainda pouco conhecida, mas, seriamente ameaçada.

Keywords: ANOSIM, Community ecology, Functional ecology, RLQ analysis, Tocantins-Araguaia river basin.

\section{Introduction}

A central challenge of ecological research relies on revealing how diversity is structured through space and which factors are responsible for such organization. An observed pattern in ecology is the decrease of compositional similarity between localities as distance increases (Nekola \&
White, 1999), often as a consequence of dispersal limitation through geographic barriers or spatially structured environmental gradients (Olden et al., 2010). In freshwater systems, remarkable differences in fish species composition among localities of distinct basins have been observed in temperate (Cross et al., 1986; Swift et al., 1986; Matthews \& Robinson, 1988) and tropical (Mendonça et al., 2005)

${ }^{1}$ Departamento de Biologia, Universidade Estadual de Goiás, Campus Palmeiras de Goiás, Palmeiras de Goiás, Rua S-7, S/N, Setor Sul, 76190-000 Palmeiras de Goiás, GO, Brazil. decarvalho.ra@gmail.com (corresponding author)

${ }^{2}$ Universidade Federal de Goiás, Instituto de Ciências Biológicas, Departamento de Ecologia, Programa de Pós-graduação em Ecologia e Evolução, Rodovia Goiânia-Nerópolis km 5, Campus II Itatiaia, 74001-970 Goiânia, GO, Brazil.

${ }^{3}$ Pontifícia Universidade Católica de Goiás - Campus II, Centro de Biologia Aquática, Av. Engler s/n, Jardim Mariliza, $74605-010$ Goiânia, GO, Brazil. garro@pucgoias.edu.br

${ }^{4}$ UniEvangélica, Programa de Pós-graduação em Sociedade, Tecnologia e Meio Ambiente, Av. Universitária km. 3,5 - Cidade Universitária, 75083-515 Anápolis, GO, Brazil. 
regions, reinforcing the idea that the regional biogeography of fish assemblages is frequently limited by drainage basin limits (Gilbert, 1980). In this context, one may expect a higher degree of similarity between species composition of any localities within a basin than with species composition of localities at neighboring basins (Matthews, 1998). However, while species composition of fish assemblages is strongly influenced by historical and geographical factors, functional traits composition is mainly structured by local environmental drivers (Hoeinghaus et al., 2007), such as: hydrological factors (Poff \& Allan, 1995; Lamouroux et al., 2002), habitat features (Hoeinghaus et al., 2007; Teresa \& Casatti, 2012), environmental gradients (Ibañez et al., 2007; Pease et al., 2012) and urbanization (Cunico et al., 2011).

The hypothesis of community convergence predicts that distant and unrelated communities (or assemblages) will converge in their species traits composition when living under similar environmental conditions (Ricklefs, 2006). As a consequence, fish assemblages' traits composition of separated hydrographic basins will be dissimilar if abiotic characteristics of their environments are different. Several studies described species traits similarities among fish assemblages of distinct regions. For example, Lamouroux et al. (2002) found out that fish assemblages from European and North American streams are similar along geomorphic and hydraulic gradients for most biological traits evaluated in their study. Ibañez et al. (2009) described similar patterns for invertivorous and omnivorous fish species among fish assemblages of tropical and temperate regions. Logez et al. (2010) demonstrated that stream fish assemblages from Mediterranean and western European responded in a similar way along environmental gradients. Cunico et al. (2011) also found similarity between species functional traits of fish assemblages from Brazil and USA urban streams despite their differences in species composition. In freshwater systems, headwater streams are suitable habitats to test the consequences of community convergence hypotheses since they, as all lotic systems, are usually regulated by similar physical processes (Lamouroux et al., 2002), which together with other abiotic factors may predominate over biotic interactions (Ostrand \& Wilde, 2002; Grenouillet et al., 2004).

In this paper, we used a dataset of 25 headwater streams distributed between two adjacent basins of Central Brazil (Araguaia and Tocantins river basins) to unveil functional patterns of their fish assemblages. In consequence of community convergence, we expect that headwater stream fish assemblages of both basins will be more functionally similar than expected by chance because of similar environmental conditions. Our main goal in this study is to answer the following questions: $i$ ) Are headwater fish assemblages of the Araguaia and Tocantins basins more functionally (dis)similar than expected by chance?; ii) If dissimilar, are the environmental differences driving the inter-basin pattern of assemblages' functional differentiation?

\section{Material and Methods}

Study area. The Tocantins-Araguaia river basins is one of the most important watersheds in the Amazonian province (Ribeiro et al., 1995; Lévêque et al., 2008). The drainage area of the rio Araguaia (hereafter Araguaia basin) and the rio Tocantins (hereafter Tocantins basin) are adjacent in Central Brazil. In this region, they are geographically separated by Serra do Caiapó and Serra dos Pirineus (Tejerina-Garro, 2008) and possess distinct physiographic units along their longitudinal profiles (Ribeiro et al., 1995). Added to these physiographic disparities, rio Araguaia is known as a floodplain river with a low drainage density and it remains connected with its principal tributaries during the wet season, whereas the rio Tocantins is a channelized river with a high drainage density and fewer floodplain lakes (Ribeiro et al., 1995).

Data and sampling protocol. Analyses were performed on data from 25 headwater streams distributed between Araguaia (13) and Tocantins (12) basins (Fig. 1). We considered a stream as a headwater by its location in the river system $\left(1^{\text {st }}-3^{\text {rd }}\right.$ order; Vannote et al., 1980) and drainage area $\left(10<\right.$ drainage area $<1,000 \mathrm{~km}^{2}$; Meybeck et al., 1996). We determined stream order using Strahler's modification of Horton's scale (Petts, 1994). We checked streams location and order using a geographical information system map $(1: 250,000)$, available in the website of the Sistema Estadual de Estatística e de Informação Geográfica de Goiás (SIEG, 2014).

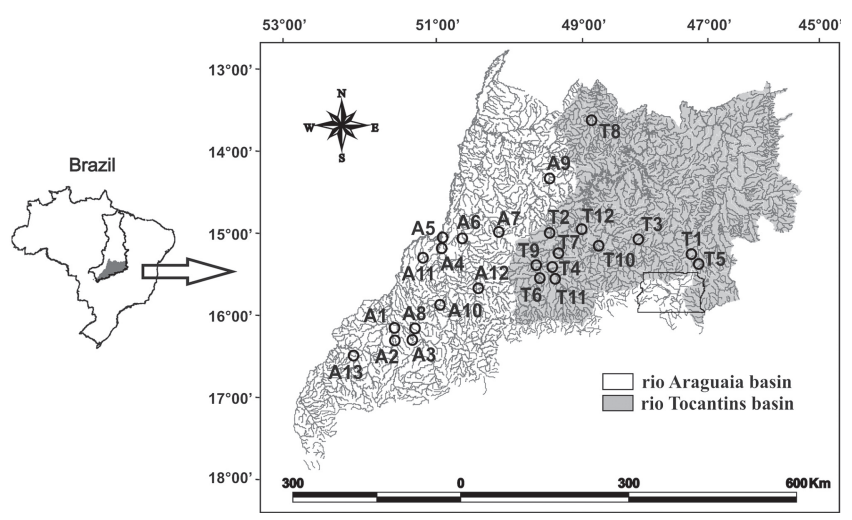

Fig. 1. Locality of streams sampled in the Araguaia (A1A13) and Tocantins (T1-T12) river basins, Central Brazil. Tocantins-Araguaia basin is represented in the small map of Brazil.

All headwater streams were sampled during dry season - May to September 2008 - when fishes are captured more efficiently (Pease et al., 2012) and the relationship between habitat and fish assemblage structure is stronger (Willis et al., 2005). For each stream, a reach of $50 \mathrm{~m}$ was defined and fish species were sampled with a seine net $(4 \mathrm{~m} \times 1,5 \mathrm{~m} \times$ $1 \mathrm{~cm}$ of mesh between opposing knots), which is an efficient sampling technique when the focus is on ecological patterns 
of species richness and composition (Medeiros et al., 2010). The sampling effort was standard for all reaches, that is, ten passes along the reach by two persons handling the seine net. All specimens collected were stored in the collection of the Centro de Biologia Aquática Pontifícia Universidade Católica de Goiás for a first triage. After that, fish specimens were sent to the laboratório de Ictiologia do Museu de Ciências e Tecnologia da Pontifícia Universidade Católica do Rio Grande do Sul for identification.

Species traits and environmental variables. For all fish species, we collected data for eight functional traits: average body mass, trophic guild, water column position, parental care, foraging locality, substrate preference, foraging method and migration (Table 1 and supplementary material in Table S1). Body mass was calculated as the mean value for all organisms of the species. The substrate preference and the foraging method were obtained from field data. To determine substrate preference all locations where the species was collected were evaluated and the substrate(s) identified. Then, for each species, we calculated their occurrence frequency in each substrate. The substrate preference was the substrate where the species had higher frequency of occurrence. Foraging locality was determined according to streams velocity, and we considered streams with water velocity superior to $20 \mathrm{~cm} / \mathrm{s}$ as running waters (riffles) while streams under this limit as standing waters, slower pools (see Rezende, 2007). The other functional traits were obtained from specialized literature (Melo, 2011) and an on-line database for fishes (Froese \& Pauly, 2014). If information for a species was not found, the data for the genus or family was extrapolated to the species level. If there was only one species in the genus and extrapolation was not possible, we considered species trait as not available (NA).

For each reach, three transversal transects were delimited and used to measure eight environmental variables: altitude (m), channel depth (m), channel width (m), turbidity (NTU), $\mathrm{pH}$, conductivity $\left(\mu \mathrm{S} . \mathrm{cm}^{-1}\right)$, dissolved oxygen $\left(\mathrm{mg} . \mathrm{l}^{-1}\right)$, and water temperature $\left({ }^{\circ} \mathrm{C}\right)$. Altitude was measured in the first transect with a GPS (Garmin 12) and turbidity was measured in the middle transect with a turbidimeter (LaMotte 2020). All other variables were measured in all transects using: an oximeter (Lutron YK-22DO) for dissolved oxygen and temperature, a conductivity meter (WTW 315i) for conductivity, a measuring rope for channel depth, a rangefinder (Bushnell-Yardage Pro 500) for channel width distance and a pH meter (Lutron $\mathrm{PH}-208$ ) for $\mathrm{pH}$. For each environmental variable measured in more than one transect, we used in our analyses the mean value of the variable for all transects.

Analyses. Based on the available data, we constructed three matrices for analyses: a presence-absence matrix (species $v s$. site), an environmental matrix (environmental variables $v s$. site) and a functional traits matrix (species $v s$. traits). To test for functional dissimilarities between headwater fish assemblages of both basins, we ran a one-way analysis of similarities (ANOSIM) that is a non-parametric variant of analysis of variance (Clarke, 1993). This statistical method operates directly on a dissimilarity matrix and computes if differences between groups are greater than those within groups (Oksanen et al., 2014). We performed the ANOSIM using a functional dissimilarity matrix among communities that was obtained using a double principal coordinate analysis (DPCoA). It takes into account differences between species to describe the diversity of a community and, then, computes differences between two communities (Pavoine et al., 2004). Since we had qualitative and quantitative traits together in our functional matrix, we used a modification of Gower distance to obtain the dissimilarity matrix (Pavoine et al., 2009). We ran ANOSIM with 999 permutations. All analyses were performed in the R software (R Development Core Team, 2014).

Table 1. Category and codes by functional trait of fish species sampled in 25 headwater streams of Araguaia and Tocantins river basins.

\begin{tabular}{|c|c|c|}
\hline Trait & Category & Code \\
\hline Average body mass (g) & Average body mass & $\mathrm{ABM}$ \\
\hline \multirow{5}{*}{ Trophic guild } & Algivorous & $\mathrm{A}$ \\
\hline & Omnivorous & $\mathrm{O}$ \\
\hline & Carnivorous & $\mathrm{C}$ \\
\hline & Detritivorous & $\mathrm{D}$ \\
\hline & Invertivorous & I \\
\hline \multirow{2}{*}{ Parental care } & Parental care & Y \\
\hline & No parental care & $\mathrm{N}$ \\
\hline \multirow{3}{*}{ Water column position } & Benthic & $\mathrm{BE}$ \\
\hline & Pelagic & $\mathrm{P}$ \\
\hline & Benthopelagic & $\mathrm{BP}$ \\
\hline \multirow{3}{*}{ Foraging method } & Visual feeding & $\mathrm{V}$ \\
\hline & Barbells & B \\
\hline & Electricity & E \\
\hline \multirow{6}{*}{ Substrate preference } & Sand & S \\
\hline & Gravel & G \\
\hline & Rock & $\mathrm{R}$ \\
\hline & Sand/gravel & SG \\
\hline & Sand/rock & SR \\
\hline & Gravel/rock & GR \\
\hline \multirow{2}{*}{ Foraging locality } & Lentic & LE \\
\hline & Lotic & $\mathrm{L}$ \\
\hline \multirow{2}{*}{ Migration } & Migratory & M \\
\hline & Non-migratory & NM \\
\hline
\end{tabular}

To test for functional traits response to environmental conditions we used a combination of two methods: RLQ (Dolédec et al., 1996) and fourth-corner analysis (Legendre et al., 1997). Both methods are based on the analysis of three matrices: R (environmental characteristics of sampling locations), $\mathrm{L}$ (species distribution across sampling locations) and Q (species traits). The RLQ method is a multivariate technique that performs a double inertia analysis of matrices 
$\mathrm{R}$ and $\mathrm{Q}$, assuming that matrix $\mathrm{L}$ is the link between environment and species traits (Dolédec et al., 1996). Initially, matrices $\mathrm{R}$ and $\mathrm{Q}$ are submitted to an ordination method (principal coordinate analysis, PCA) and, then, used to constrain a correspondence analysis of the central matrix L (Dray et al., 2003) followed by a Monte Carlo permutation test (999 iterations with a sequential approach; ter Braak et al., 2012). The analysis produces a matrix that describes traits-environment associations, called fourth-corner matrix, which summarizes the joint structure of the three matrices (Dray et al., 2014). The fourth-corner method also combines matrices $\mathrm{R}, \mathrm{L}$ and $\mathrm{Q}$ into a single matrix describing traits-environment associations (fourth-corner matrix; Legendre et al., 1997). Additionally, this analysis tests the relationship between one trait and one environmental variable at a time, allowing the evaluation of individual trait-environmental relationships. When the evaluated relationship is between two quantitative variables the link is measured by a Pearson correlation, but when the evaluated relationship is between one quantitative and one qualitative variable the link is measured by Pseudo-F or Pearson $r$ (Dray \& Legendre, 2008). For fourth-corner analysis, we performed a log-transformation on each environmental variable, excepting for $\mathrm{pH}$, to increase linearity and avoid extreme values, given the different nature and scale of them. RLQ and fourth-corner are complementary methods and their combined use may improve strongly the study of traitenvironment associations (Dray et al., 2014). To run RLQ and fourth-corner analyses, we used the package ADE-4 (Dray \& Dufour, 2007) implemented in the R software (R Development Core Team, 2014).

\section{Results}

We found 62 species occurring in the 25 headwater streams sampled. Forty-nine species were found in the streams of the Araguaia basin, while 37 species were found in those of the Tocantins basin, and 24 species were common to streams of both basins (Table 2). The average species richness for Araguaia basin streams was 9.69, while for the streams of the Tocantins basin was 7.41.
Conversely to the expected, we found functional dissimilarity between fish assemblages of both basins (ANOSIM; $\mathrm{R}=0.09, \mathrm{p}=0.03$ ). The results of the RLQ analysis revealed significant relationship between fish species traits and environmental variables $(p=0.01$, Monte Carlo permutation test; Table 3) with the first and the second axes accounting for $40.54 \%$ and $25.76 \%$ of the total variance, respectively. The RLQ and fourth-corner analysis indicated that the first axis is related to inter-basin dissimilarities that are mainly driven by the environmental variables altitude and water temperature (Figs. 2a-c). Interbasin dissimilarities are more accentuated for the altitudinal and water temperature gradients. Ten of the 12 streams of the Tocantins basin displayed high altitudinal values (from 534 to $942 \mathrm{~m}$ ), while 12 of 13 streams of the Araguaia basin low values ( 218 to $400 \mathrm{~m}$ ); nine of the 12 streams of the Tocantins basin displayed low water temperature (17.3 to $22.6^{\circ} \mathrm{C}$ ), while eigth of 13 streams of the Araguaia basin high water temperature $\left(24.1\right.$ to $\left.27.5^{\circ} \mathrm{C}\right)$. On the other hand, the second axis is related to dissimilarities among streams independently of the basin and mostly driven by turbidity, channel depth and conductivity (Figs. 2a-c).

The five environmental variables influenced principally on six species traits: average body mass, parental care, water column position, foraging locality, substrate preference and migration (Table 3 and Figs. 2c-d). Average body mass is positively correlated to the altitudinal gradient $(\mathrm{p}<0.01)$, but it is negatively correlated to channel depth $(\mathrm{p}<0.01)$. The presence of fish species displaying parental care is associated to an increase of water turbidity $(p=0.04)$. Fish water column position is influenced by gradients of altitude $(p=0.04)$, turbidity $(p=0.03)$ and conductivity $(p=0.01)$. Benthic species are negatively associated to altitude $(\mathrm{p}=$ $0.01)$ and positively to turbidity $(\mathrm{p}=0.01)$ and conductivity $(p=0.02)$. Fish species preference for gravel is positively correlated with altitude $(p=0.01)$ while preference for sand/ gravel substrate is negatively correlated to this variable $(\mathrm{p}$ $=0.01$ ). Foraging locality is influenced by conductivity ( $\mathrm{p}=$ 0.02 ), regardless of category considered. A similar situation is observed for the relationship between migration and water temperature (Table 3).

Table 2. Code and voucher number $(\mathrm{MCP}=$ Museu de Ciências e Tecnologia da Pontifícia Universidade Católica do Rio Grande do Sul) of species sampled in 25 headwater streams of Araguaia (A) and Tocantins (T) river basins. NA=not available.

\begin{tabular}{|c|c|c|c|c|}
\hline \multirow{2}{*}{ Species } & \multirow{2}{*}{ Code } & \multicolumn{2}{|c|}{ Basin } & \multirow[t]{2}{*}{ MCP } \\
\hline & & $\mathbf{A}$ & $\mathbf{T}$ & \\
\hline Aequidens tetramerus (Heckel, 1840) & AEQTET & $\mathrm{x}$ & $\mathrm{x}$ & 45538 \\
\hline Apareiodon sp. & APASP & $\mathrm{x}$ & & NA \\
\hline Apareiodon sp. 2 & APASP2 & & $\mathrm{x}$ & NA \\
\hline Aphyocharax sp. & APHSP & & $\mathrm{x}$ & 45592 \\
\hline Apistogramma sp. & APISP & & $\mathrm{x}$ & 45618 \\
\hline Astyanax fasciatus (Cuvier, 1819) & ASTFAS & $\mathrm{x}$ & $\mathrm{x}$ & 44676 \\
\hline Astyanax sp. 1 & ASTSP1 & $\mathrm{x}$ & $\mathrm{x}$ & 45522 \\
\hline
\end{tabular}




\begin{tabular}{|c|c|c|c|c|}
\hline \multirow{2}{*}{ Species } & \multirow{2}{*}{ Code } & \multicolumn{2}{|c|}{ Basin } & \multirow[t]{2}{*}{ MCP } \\
\hline & & $\mathbf{A}$ & $\mathbf{T}$ & \\
\hline Astyanax sp. 2 & ASTSP2 & $\mathrm{x}$ & $\mathrm{x}$ & 45609 \\
\hline Astyanax sp. 3 & ASTSP3 & $\mathrm{x}$ & $\mathrm{x}$ & 45520 \\
\hline Bryconamericus sp. 2 & BRYSP2 & & $\mathrm{x}$ & 45572 \\
\hline Bryconamericus sp. 3 & BRYSP3 & & $\mathrm{x}$ & NA \\
\hline Bryconops caudomaculatus (Günther, 1864) & BRYCAU & $\mathrm{x}$ & $\mathrm{x}$ & 44622 \\
\hline Characidium zebra Eigenmann, 1909 & CHAZEB & $\mathrm{x}$ & $\mathrm{x}$ & 45518 \\
\hline Charax gibbosus (Linnaeus, 1758) & CHAGIB & $\mathrm{x}$ & & 45539 \\
\hline Corydoras sp. & CORSP & & $\mathrm{x}$ & 45585 \\
\hline Creagrutus sp. & CRESP & $\mathrm{x}$ & $\mathrm{x}$ & 44603 \\
\hline Curimatella sp. & CURSP & $\mathrm{x}$ & & 45576 \\
\hline Cyphocharax spiluropsis (Eigenmann \& Eigenmann, 1889) & CYPSPI & $\mathrm{x}$ & & 45582 \\
\hline Eigenmannia virescens (Valenciennes, 1836) & EIGVIR & $\mathrm{x}$ & $\mathrm{x}$ & 45528 \\
\hline Farlowella amazonum (Günther, 1864) & FARAMA & & $\mathrm{x}$ & 45630 \\
\hline Galeocharax gulo (Cope, 1870) & GALGUL & & $\mathrm{x}$ & 45561 \\
\hline Hemigrammus sp. & HEMSP & $\mathrm{x}$ & $\mathrm{x}$ & 45519 \\
\hline Hoplias malabaricus (Bloch, 1794) & HOPMAL & $\mathrm{x}$ & $\mathrm{x}$ & 44702 \\
\hline Hyphessobrycon sp. & HYPSP & $\mathrm{x}$ & $\mathrm{x}$ & NA \\
\hline Hypostomus plecostomus (Linnaeus, 1758) & HYPPLE & $\mathrm{x}$ & $\mathrm{x}$ & 44698 \\
\hline Hypostomus sp. 1 & HYPSP1 & $\mathrm{x}$ & & 45554 \\
\hline Iguanodectes spilurus (Günther, 1864) & IGUSPI & $\mathrm{x}$ & & 44629 \\
\hline Imparfinis sp. & IMPSP & $\mathrm{x}$ & $\mathrm{x}$ & 45523 \\
\hline Jupiaba polylepis (Günther, 1864) & JUPPOL & $\mathrm{x}$ & $\mathrm{x}$ & 44618 \\
\hline Knodus sp. & KNOSP & $\mathrm{x}$ & $\mathrm{x}$ & 44615 \\
\hline Leporinus friderici (Bloch, 1794) & LEPFRI & $\mathrm{x}$ & & 44608 \\
\hline Loricaria cataphracta (Linnaeus, 1758) & LORCAT & $\mathrm{x}$ & $\mathrm{x}$ & 44700 \\
\hline Moenkhausia collettii (Steindachner, 1882) & MOECOL & $\mathrm{x}$ & & 45534 \\
\hline Moenkhausia dichroura (Kner, 1858) & MOEDIC & $\mathrm{x}$ & & 45524 \\
\hline Moenkhausia lepidura (Kner, 1858) & MOELEP & $\mathrm{x}$ & $\mathrm{x}$ & 44609 \\
\hline Moenkhausia oligolepis (Günther, 1864) & MOEOLI & $\mathrm{x}$ & $\mathrm{x}$ & 44625 \\
\hline Moenkhausia sp. 2 & MOESP2 & $\mathrm{x}$ & $\mathrm{x}$ & 45535 \\
\hline Moenkhausia sp. 5 & MOESP5 & & $\mathrm{x}$ & 44660 \\
\hline Odontostilbe sp. & ODOSP & & $\mathrm{x}$ & 44634 \\
\hline Otocinclus tapirape Britto \& Moreira, 2002 & OTOTAP & & $\mathrm{x}$ & 45623 \\
\hline Pamphorichthys sp. & PAMSP & $\mathrm{x}$ & $\mathrm{x}$ & 45565 \\
\hline Phenacogaster sp. & PHESP & $\mathrm{x}$ & $\mathrm{x}$ & 45537 \\
\hline Pimelodella cristata (Müller \& Troschel, 1849) & PIMCRI & $\mathrm{x}$ & & 45529 \\
\hline Pimelodella sp. & PIMSP & $\mathrm{x}$ & & 45584 \\
\hline Poptella longipinnis (Popta, 1901) & POPLON & $\mathrm{x}$ & $\mathrm{x}$ & 44626 \\
\hline Psellogrammus sp. & PSESP & & $\mathrm{x}$ & 44636 \\
\hline Retroculus lapidifer (Castelnau, 1855) & RETLAP & $\mathrm{x}$ & & 44694 \\
\hline Rhamdella sp. & RHASP & $\mathrm{x}$ & & NA \\
\hline Rineloricaria sp. & RINSP & $\mathrm{x}$ & $\mathrm{x}$ & 45601 \\
\hline Rineloricaria sp. 2 & RINSP2 & & $\mathrm{x}$ & 45579 \\
\hline Satanoperca acuticeps (Heckel, 1840) & SATACU & $\mathrm{x}$ & & 45629 \\
\hline Serrapinnus kriegi (Schindler, 1937) & SERKRI & $\mathrm{x}$ & & NA \\
\hline Serrapinnus sp. & SERSP & $\mathrm{x}$ & & 44637 \\
\hline Steindachnerina sp. & STESP & $\mathrm{x}$ & & 44617 \\
\hline Steindachnerina sp. 2 & STESP2 & $\mathrm{x}$ & & NA \\
\hline Tetragonopterus argenteus (Cuvier, 1816) & TETARG & $\mathrm{x}$ & & 44638 \\
\hline Tetragonopterus chalceus Spix \& Agassiz, 1829 & TETCHA & $\mathrm{x}$ & & 44601 \\
\hline Thayeria boehlkei Weitzman, 1957 & THABOE & $\mathrm{x}$ & & 45536 \\
\hline Thoracocharax stellatus (Kner, 1858) & THOSTE & $\mathrm{x}$ & & 45527 \\
\hline Trachelyopterus galeatus (Linnaeus, 1766) & TRAGAL & $\mathrm{x}$ & & 45627 \\
\hline Total species richness & & 49 & 37 & \\
\hline
\end{tabular}


Table 3. Results of the RLQ (A) and fourth-corner (B) analyses of environmental variables (variable R) and fish functional traits (variable Q) from 25 headwater streams of Araguaia and Tocantins river basins. Only results with significant values $(\mathrm{p}<0.05$; in bold $)$ are displayed.

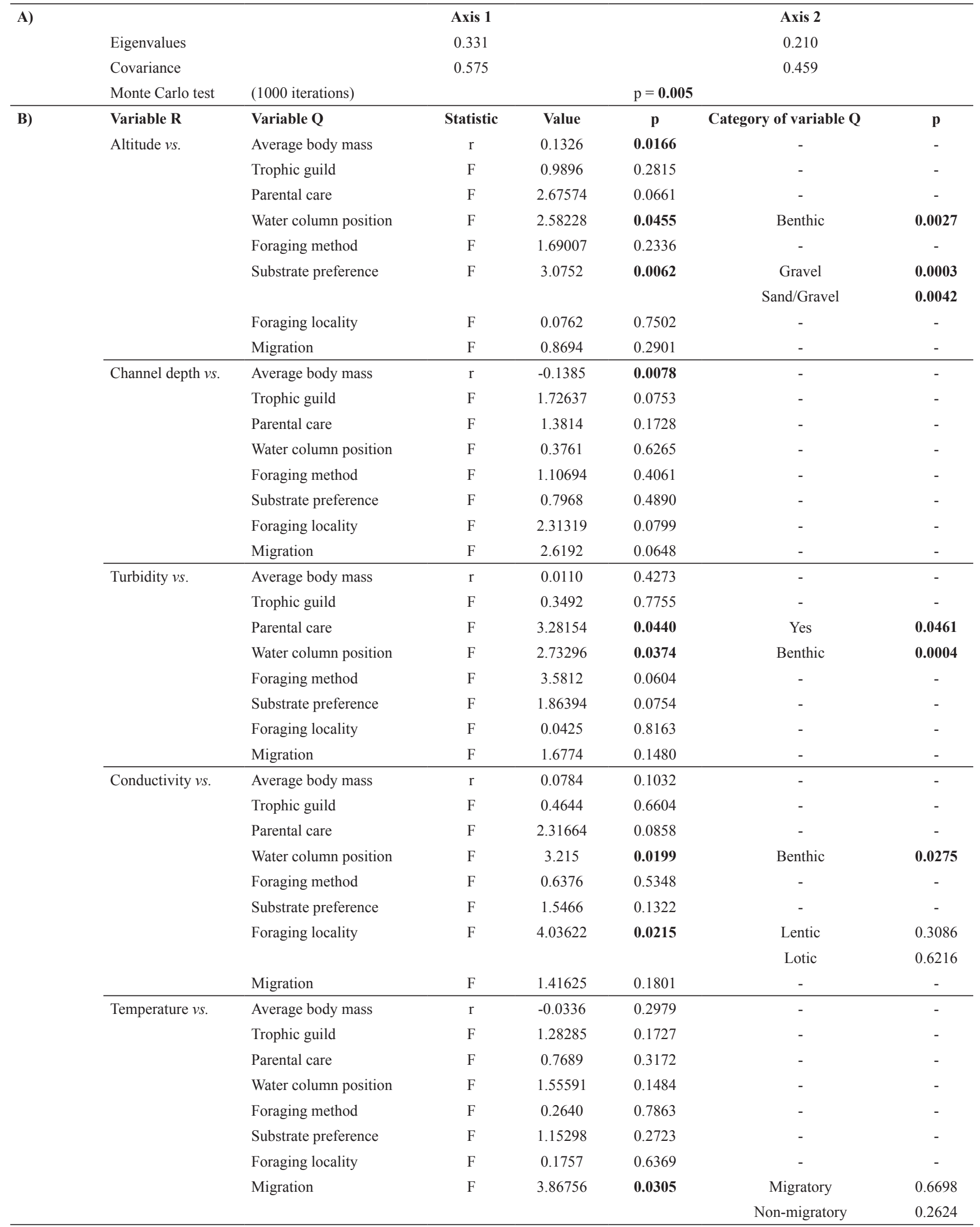




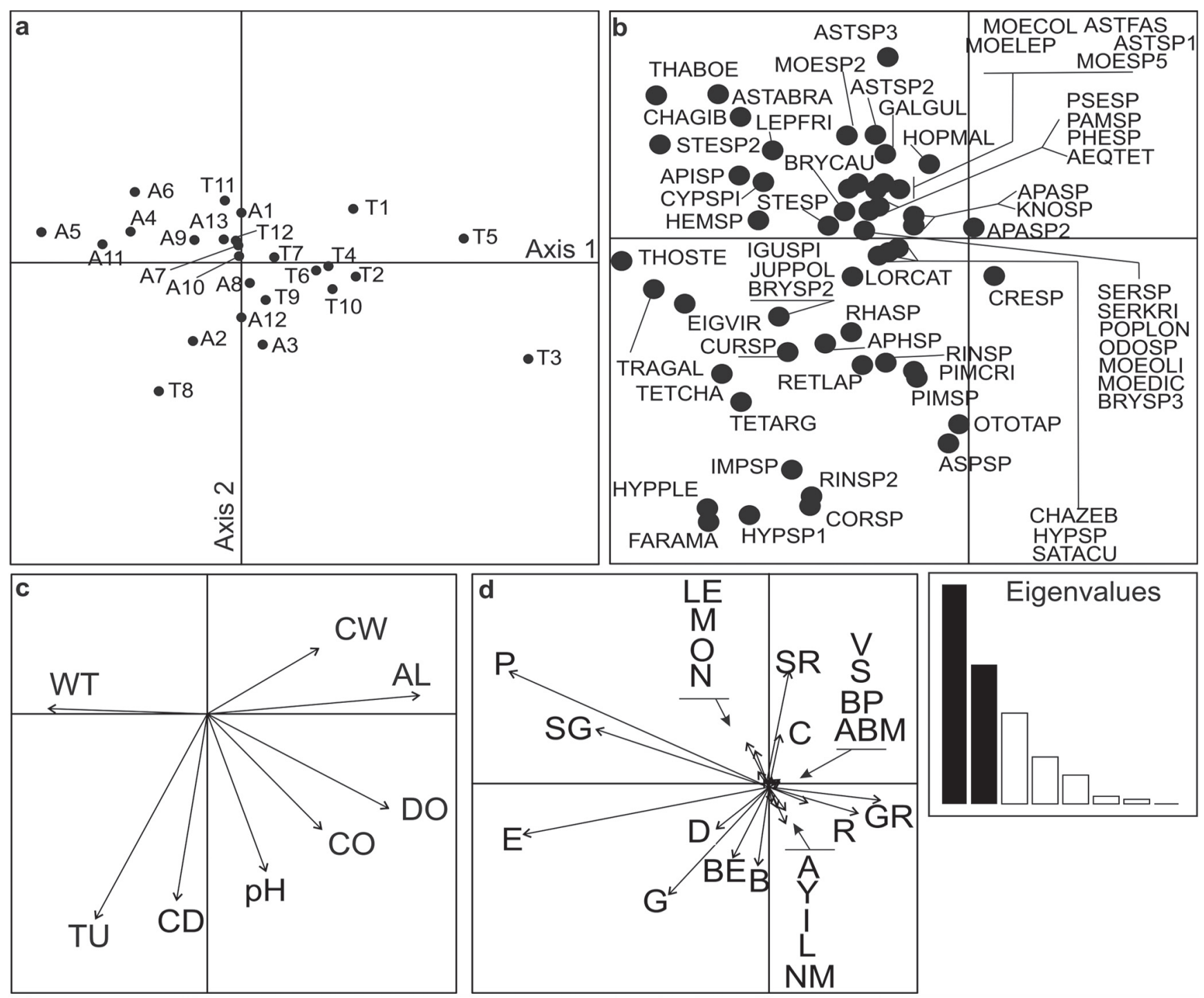

Fig. 2. Ordination of sampling stations (a), species (b), environmental variables (c) and functional traits (d) resulting of the RLQ analysis. In (a) the letter preceding numbers indicates the river basin (A=Araguaia; $\mathrm{T}=$ Tocantins). In (c) $A L=a l t i t u d e ;$ $\mathrm{CO}=$ conductivity; $\mathrm{CD}=$ channel depth; $\mathrm{CW}=$ channel width; $\mathrm{DO}=$ dissolved oxygen; $\mathrm{TU}=$ turbidity; WT=water temperature. Consult Tables 1 and 2 for codes used in (d) and (b), respectively. The eigenvalues of the axes are displayed in the smallest box with the first two axes featured in black.

\section{Discussion}

Despite the growing interest on the determinants of fish assemblages' functional structure, most studies in large scale still focus their attention on the determinants of species richness (Hoeinghaus et al., 2007) and, particularly in tropical rivers, functional traits composition of fish assemblages remains poorly known (Pease et al., 2012). Our results revealed dissimilarities between fish assemblages' functional structure of the two neighboring basins considered (Araguaia and Tocantins) driven by altitudinal and water temperature gradients. In this study, the altitude increases from east (Araguaia basin streams) to west (Tocantins basin streams) and is accompanied by a decrease in water temperature. A similar trend was observed in temperate streams, but involving latitudinal gradients and other variables than altitude and water temperature (Oliveira et al., 2012). These authors suggest that this trend corresponds to different forms of ecosystem functioning, ranging from warm water and lower altitudinal systems (in our study represented by Araguaia basin streams) to colder and high altitudinal systems (Tocantins basin streams). Schleuter et al. (2012) also observed differences between fish assemblages' functional structure of neighboring basins separated by mountain chains, as is the case of the Araguaia and Tocantins. Rahel \& Hubert (1991) pointed out that transition in biological communities due to thermal conditions is expected in mountainous regions, where water temperature decreases as altitude increases. 
Several studies pointed out the importance of abiotic factors in shaping fish assemblages' structure (Poff \& Allan, 1995; Peres-Neto, 2004; Hoeinghaus et al., 2007). Species occurrence in headwater streams are directly influenced by water velocity and stream depth (Mendonça et al., 2005, Súarez et al., 2007), whereas the functional structure of headwater streams are driven by factors such as turbidity and dissolved oxygen coupled with channel depth and water velocity (Carvalho \& Tejerina-Garro, 2015). Our results revealed that dissimilarities among the functional structure of headwater streams fish assemblages within the basins are mainly determined by channel depth, turbidity and conductivity. Channel depth is often suggested as a reasonable indicator for habitat structural complexity (Súarez et al., 2007), which may increase species traits diversity (Willis et al., 2005). Then, an increase of channel depth from one headwater stream to another may implicate in the addition of species with new and distinct traits in the fish assemblages. Turbidity and conductivity may limit species occurrence in local fish assemblages. For example, the species of catfish Aspidoras fuscoguttatus Nijssen \& Isbrücker, 1976 was already found in association with high levels of water turbidity (Araújo \& Garutti, 2003) that may affect its diet (Casatti et al., 2009). In our sampled streams, a species of the same genus (Aspidoras sp.) is also related to streams of high conductivity.

Altitude is related to the regional topography and it influences functional traits composition of fish assemblages at both regional (Oliveira et al., 2012) and local scales (Bistoni \& Hued, 2002; Pouilly et al., 2006). Our results provided evidence that altitude affects three functional traits of headwater fish species in different manners: body mass (positively), water column position (negatively to benthic species) and substrate preference (negatively to species with gravel and sand/gravel preference). Schlosser (1990) points out that fish body size (mass) tends to increase towards downstream reaches, whereas we found an opposite trend. This result suggests that changes of stream altitude (from $1^{\text {st }}$ to $3^{\text {rd }}$ order) are not enough to influence on body mass giving a direction. However, contrasting these headwater streams to those streams of downstream areas $\left(>3^{\text {rd }}\right.$ order) may reveal the expected trend mentioned by Schlosser (1990).

In temperate regions, and considering a broad longitudinal gradient, benthic species tends to be absent in headwater streams $\left(1^{\text {st }}-3^{\text {rd }}\right.$ order $)$ and present in streams of higher order $\left(>4^{\text {th }}\right)$ as a result of biotic zonation (Rahel \& Hubert, 1991). Contrary, in tropical regions, Mazzoni \& Lobón-Cerviá (2000) observed that the number of benthic species increases upstream, concluding that they did not show a longitudinal-related distributional pattern but varied inversely with channel depth. These authors suggest that this is a result of patchy availability of resources along the stream and, in this case, it is predominant over longitudinal distribution. This seems to explain our results, that is benthic species of the Araguaia and Tocantins streams do not follow a longitudinal-related distributional trend but are influenced by resources availability. Within a drainage basin, the slope and the transport of materials decreases accordingly to the altitude, thus in lower altitudes, for example $3^{\text {rd }}$ order in our study, the transport of materials is lower than upstream favoring the deposition of gravel and/or sand (Suguio \& Bigarela, 1990). Gravel favors the presence of benthic algal/detritivorous species (Mazzoni \& Lobón-Cerviá, 2000), such as the siluriforms Hypostomus plecostomus, Farlowella amazonum, Corydoras sp. in our study. These fishes have streamlined or flattened bodies with hooks or sucker structures for clinging (Moyle \& Cech, Jr. 1996) that allows inhabiting this kind of habitat.

The relationship between fish body size and channel depth is expected to be positively correlated and represented by small fish occupying shallow waters and large fish deeper waters (Vannote et al., 1980; Schlosser, 1987, 1991). This pattern seems to reduce the predation risk for both small and large fishes (Harvey \& Stewart, 1991) but fish with small body sizes are not exclusive of shallow waters and are also encountered in deeper waters (Angermeier \& Karr, 1983; Harvey \& Stewart, 1991; Stewart et al., 2002). Channel depth is a reasonable indicator for habitat structural complexity (Súarez et al., 2007), then, deeper streams should have more microhabitats for hiding and escaping from predators (Willis et al., 2005). Furthermore, these microhabitats can be explored by species with different morphologies and physiologies that reduce competition and facilitate species coexistence (Hugueny, 1990). The presence of fishes with lower body mass (small fish) in streams with higher levels of channel depth in our study area may reflects reduced levels of predation and/ or competition (Angermeier \& Karr, 1983) due to habitat structural complexity of deeper waters. Therefore, survival of small fishes would increase in streams of high channel depth explaining the trend found in this study.

Turbidity is often a consequence of suspended sediments in the water column which influences on light availability and sensory adaption of fish (visually or not oriented) to visibility of prey (Rodriguez \& Lewis, Jr., 1997, TejerinaGarro et al.; 1998) and consequently on the fish assemblage of lotic environments (Fialho et al., 2008). This can explain the relationship of elevated water turbidity and non-visually oriented benthic species as the siluriforms (e.g., Hypostomus plecostomus, Imparfinis sp., Corydoras sp.) observed in our study. On the other hand, excess of suspended sediment can promote bed sedimentation resulting in reduced egg and fry survivorship (Soulsby et al., 2001; Walters et al., 2003). In this case, parental care can increase egg survival as seems to be the case of the catfish Otocinclus tapirapae (Loricariidae), whose males may present different types of parental care (Blumer, 1982). Since turbidity may increase the levels of water conductivity (Esteves, 1988), we believe that the relationship between benthic species and conductivity is a consequence of their presence in turbid waters, as mentioned above. 
One trait related to life history of some tropical fish is seasonal migration (Winemiller, 1989; Winemiller \& Jepsen, 1998), which takes place before onset of the rainy season (Sivasundar et al., 2001). Tropical seasonality is characterized by alternance of low and high waters that is accompanied by changes of water physicochemical characteristics such as water temperature (Tockner et al., 2000). Thus, water temperature along with other variables is an environmental stimulus that directs or regulates fish migration (Northcote, 1984). This can explain the influence of water temperature on migratory habits found in this study.

In a regional scale, our findings are important for the development of future conservation strategies in these systems. If headwater streams fish assemblages of the Araguaia and Tocantins basins differ in species traits composition, conservation strategies should focus their attention on areas that are capable of representing species and functional traits of both basins. Otherwise, they might fail in protecting the diversity of species functional traits of these basins. In this scale, some attention should be given for the following species functional traits: body mass, water column position, preference for substrate and migratory habits. These traits were the most influenced by gradients of altitude and water temperature that drive dissimilarities between both basins. In a local scale, we showed that functional differences among headwater streams were driven mainly by channel depth, turbidity and conductivity. Such environmental drivers influenced fish body mass, presence or absence of species with (or without) parental care, water column position and foraging locality. Local management for the protection of headwater stream fish assemblages should consider these speciestraits relationships.

Understandingspecies-traits relationshipsis aprimordial step for unrevealing how communities (or assemblages) are structured and which factors are responsible for such organization. This study is an attempt to unveil the functional patterns of fish assemblages in a tropical region that continues to be poorly known but severely threatened. Focus on new species traits and environmental drivers should enhance our future knowledge on the functional structure of these systems.

\section{Acknowledgements}

We are grateful to all people of the Centro de Biologia Aquática (CBA), especially to: Waldeir Francisco de Menezes, Nicelly Braudes de Araújo, Tatiana Melo, Thiago Vieira and Bruno Bastos for collection of field data. We are also grateful to: Fabrício Barreto Teresa for helping with DPCoA protocols, Fernando Assis de Carvalho for assistance with grammar review, researchers from Pontifícia Universidade Católica do Rio Grande do Sul for fish species identification, and anonymous reviewers that contributed with insightful suggestions that improved the initial draft of this study. We thank to the Conselho Nacional de Desenvolvimento Científico e Tecnológico (CNPq) for the financial support given for the project $\left(\mathrm{CNPq} \mathrm{N}{ }^{\circ}\right.$ 471283/2006-1) and to Coordenação de Aperfeiçoamento de Pessoal de Nível Superior (CAPES) for the scholarship granted to RAC.

\section{References}

Angermeier, P. L. \& J. R. Karr. 1983. Fish communities along environmental gradients in a system of tropical streams. Environmental Biology of Fishes, 9: 117-135.

Araújo, R. B. \& V. Garutti. 2003. Ecology of a stream from upper Paraná River Basin inhabited by Aspidoras fuscoguttatus Nijssen \& Isbrücker, 1976 (Siluriformes, Callichthyidae). Brazilian Journal of Biology, 63: 363-372.

Bistoni, M. A. \& A. C. Hued. 2002. Patterns of fish species richness in rivers of the central region of Argentina. Brazilian Journal of Biology, 62: 753-764.

Blumer, L. S. 1982. A bibliography and categorization of bony fishes exhibiting parental care. Zoological Journal of the Linnean Society, 76: 1-22.

ter Braak, C. J. F., A. Cormont \& S. Dray. 2012. Improved testing of species traits-environment relationships in the fourth-corner problem. Ecology, 93: 1525-1526.

Carvalho, R. A. \& F. L. Tejerina-Garro. 2015. Environmental and spatial processes: what controls the functional structure of fish assemblages in tropical rivers and headwater streams? Ecology of Freshwater Fish, 24: 317-328.

Casatti, L., J. L. Veronezi Junior \& C. P. Ferreira. 2009. Dieta do cascudo Aspidoras fuscoguttatus (Ostariophysi, Callichthyidae) em riachos com diferentes características limnológicas e estruturais. Biota Neotropica, 9: 113-121.

Clarke, K. R. 1993. Non-parametric multivariate analysis of changes in community structure. Australian Journal of Ecology, 18: 117-143.

Cross, F. B., R. L. Mayden \& J. D. Stewart. 1986. Fishes in the western Mississippi drainage. Pp. 363-412. In: Hocutt, C. H. \& E. O. Wiley (Eds.). The Zoogeography of North American freshwater fishes. New York, Wiley.

Cunico, A. M., J. D. Allan \& A. A. Agostinho. 2011. Functional convergence of fish assemblages in urban streams of Brazil and the United States. Ecological Indicators, 11: 1354-1359.

Dolédec, S., D. Chessel, C. J. F. ter Braak \& S. Champely. 1996. Matching species traits to environmental variables: a new three-table ordination method. Environmental and Ecological Statistics, 3: 143-166.

Dray, S., D. Chessel \& J. Thioulouse. 2003. Co-inertia analysis and the linking of ecological data tables. Ecology, 84: 30783089.

Dray, S., P. Choler, S. Dolédec, P. R. Peres-Neto, W. Thuiller, S. Pavoine \& C. J. F. ter Braak. 2014. Combining the fourthcorner and the RLQ methods for assessing trait responses to environmental variation. Ecology, 95: 14-21.

Dray, S. \& A. B. Dufour. 2007. The ade4 package: implementing the duality diagram for ecologists. Journal of Statistical Software, 22: 1-20.

Dray, S. \& P. Legendre. 2008. Testing the species traitsenvironment relationships: the fourth-corner problem revisited. Ecology, 89: 3400-3412. 
Esteves, F. A. 1988. Fundamentos de Limnologia. Rio de Janeiro, Interciência, 602p.

Fialho, A.P., L. G. Oliveira, F. L. Tejerina-Garro \& B. de Mérona. 2008. Fish-habitat relationship in a tropical river under anthropogenic influences. Hydrobiologia, 598: 315324.

Froese, R. \& D. Pauly. 2014. FishBase. Available from: http:// www.fishbase.org (01/05/2014).

Gilbert, C. R. 1980. Zoogeographic factors in relation to biological monitoring of fish. Pp. 309-355. In: Hocutt, C. H. \& J. R. Stauffer, Jr. (Eds.). Biological monitoring of fish. Lexington, Mass., Lexington books.

Grenouillet, G., D. Pont \& C. Hérissé. 2004. Within-basin fish assemblage structure: the relative influence of habitat versus stream spatial position on local species richness. Canadian Journal of Fisheries and Aquatic Sciences, 61: 93-102.

Harvey, B. C. \& A. J. Stewart. 1991. Fish size and habitat depth relationships in headwater streams. Oecologia, 87: 336342 .

Hoeinghaus, D. J., K. O. Winemiller \& J. S. Birbaum. 2007. Local and regional determinants of stream fish assemblage structure: inferences based on taxonomic vs. functional groups. Journal of Biogeography, 34: 324-338.

Hugueny, B. 1990. Richesse des peuplements de poissons dans le Niandan (haut Niger, Afrique) en fonction de la taille de la rivière et de la diversité de milieu. Revue d'Hydrobiologie Tropicale, 23: 351-364.

Ibañez, C., J. Belliard, R. M. Hughes, P. Irz, A. KamdemToham, N. Lamouroux, P. A. Tedesco \& T. Oberdorff. 2009. Convergence of temperate and tropical stream fish assemblages. Ecography, 32: 658-670.

Ibañez, C., T. Oberdorff, G. Teugels, V. Mamononekene, S. Lavoué, Y. Fermon, D. Paugy \& A. K. Toham. 2007. Fish assemblages structure and function along environmental gradients in rivers of Gabon (Africa). Ecology of Freshwater Fish, 16: 315-334.

Lamouroux, N., N. L. Poff \& P. L. Angermeier. 2002. Intercontinental convergence of stream fish community traits along geomorphic and hydraulic gradients. Ecology, 83: 1792-1807.

Legendre, P., R. Galzin \& M. L. Harmelin-Vivien. 1997. Relating behavior to habitat: solutions to the fourth-corner problem. Ecology, 78: 547-562.

Lévêque, C., T. Oberdorff, D. Paugy, M. L. J. Stiassny \& P. A. Tedesco. 2008. Global diversity of fish (Pisces) in freshwater. Hydrobiologia, 595: 545-567.

Logez, M., D. Pont \& M. T. Ferreira. 2010. Do Iberian and European fish faunas exhibit convergent functional structure along environmental gradients? Journal of the North American Benthological Society, 29: 1310-1323.

Matthews, W. J. 1998. Patterns in freshwater fish ecology. New York, Chapman \& Hall. p. 191-263. Matthews, W. J. \& H. W. Robinson. 1988. The distribution of the fishes of Arkansas: a multivariate analysis. Copeia, 2: 358-374.

Mazzoni, R. \& J. Lobón-Cerviá. 2000. Longitudinal structure, density and production rates of a neotropical stream fish assemblage: the river Ubatiba in the Serra do Mar, southeast Brazil. Ecography, 23: 588-602.

Medeiros, E. S. F., M. J. Silva, B. R. S. Figueiredo, T. P. A. Ramos \& R. T. C. Ramos. 2010. Effects of fishing technique on assessing species composition in aquatic systems in semiarid Brazil. Brazilian Journal of Biology, 70: 255-262.
Melo, T. L. 2011. Avaliação espacial das variáveis ambientais e da estrutura trófica da ictiofauna de tributários da bacia Tocantins-Araguaia, Brasil Central. Unpublished Ph.D. Dissertation, Universidade Federal de São Carlos, São Carlos, 71p.

Mendonça, F. P., W. E. Magnusson \& J. Zuanon. 2005. Relationships between habitat characteristics and fish assemblages in small streams of Central Amazonia. Copeia, 4: 751-764.

Meybeck, M., G. Friedrich, R. Thomas \& D. Chapman. 1996. Rivers. Pp. 243-318. In: Chapman, D. (Ed.). Water quality assessments: a guide to use of biota, sediments and water in environmental monitoring. 2nd ed. Paris, UNESCO/Who/ Unep.

Moyle, P. B. \& J. J. Cech, Jr. 1996. Fishes: an introduction to Ichthyology. 3rd ed. Upper Saddle River, NJ, Prentice-Hall. $590 \mathrm{p}$.

Nekola, J. C. \& P. S. White. 1999. The distance decay of similarity in biogeography and ecology. Journal of Biogeography, 26: 867-878.

Northcote, T. G. 1984. Mechanisms of fish migration in rivers. Pp. 317-355. In: McCleave, J. D., G. P. Arnold, J. J. Dodson \& W. H. Neill (Eds.). Mechanisms of migration in fishes. New York, Plenum Press.

Oksanen, J., F. G. Blanchet, R. Kindt, P. Legendre, P. R. Minchin, R. B. O'Hara, G. L. Simpson, P. Solymos, M. H. H. Stevens \& H. Wagner. 2014. Vegan: Community Ecology Package. $\mathrm{R}$ package version 2.0-6. Available from: http://CRAN.Rproject.org $/$ package $=$ vegan $/(05 / 2014)$.

Olden, J. D., M. J. Kennard, F. Leprieur, P. A. Tedesco, K. O. Winemiller \& E. García-Berthou. 2010. Conservation biogeography of freshwater fishes: recent progress and future challenges. Diversity and Distributions, 16: 496-513.

Oliveira, J. M., P. Segurado, J. M. Santos, A. Teixeira, M. T. Ferreira \& R. V. Cortes. 2012. Modelling stream-fish functional traits in reference conditions: regional and local environmental correlates. PLoS ONE, 7: e45787.

Ostrand, K. G. \& G. R Wilde. 2002. Seasonal and spatial variation in a prairie stream-fish assemblage. Ecology of Freshwater Fish, 11: 137-149.

Pavoine, S., A. B. Dufour \& D. Chessel. 2004. From dissimilarities among species to dissimilarities among communities: a double principal coordinate analysis. Journal of Theoretical Biology, 228: 523-537.

Pavoine, S., J. Vallet, A. B. Dufour, S. Gachet \& H. Daniel. 2009. On the challenge of treating various types of variables: application for improving the measurement of functional diversity. Oikos, 118: 391-402.

Pease, A. A., A. A. González-Díaz, R. Rodiles-Hernández. \& K. O. Winemiller. 2012. Functional diversity and traitenvironment relationships of stream fish assemblages in a large tropical catchment. Freshwater Biology, 57: 1060-1075.

Peres-Neto, P. R. 2004. Patterns in the co-occurrence of fish species in streams: the role of site suitability, morphology and phylogeny versus species interactions. Oecologia, 140: 352-360.

Petts, G. E. 1994. Rivers: dynamic components of catchment ecosystems. Pp. 3-22. In: Calow, P. \& G. E. Petts (Eds.). The rivers handbook: hydrological and ecological principles. London, Blackwell Science. v2.

Poff, N. L. \& J. D. Allan. 1995. Functional organization of stream fish assemblages in relation to hydrological variability. Ecology, 76: 606-627. 
Pouilly, M., S. Barrera \& C. Rosales. 2006. Changes of taxonomic and trophic structure of fish assemblages along an environmental gradient in the upper Beni watershed (Bolívia). Journal of Fish Biology, 68: 137-156.

Rahel, F. J. \& W. A. Hubert. 1991. Fish assemblages and habitat gradients in a Rocky Mountain-Great Plains stream: biotic zonation and additive patterns of community change. Transactions of the American Fisheries Society, 120: 319332.

R Development Core Team. 2014. R: A language and environment for statistical computing. R Foundation for Statistical Computing, Vienna, Austria. Available from: http://www.Rproject.org/ (01/05/2014).

Rezende, C. F. 2007. Estrutura da Comunidade de Macroinvertebrados associados ao folhiço submerso de remanso e correnteza em igarapés da Amazônia Central. Biota Neotropica, 7: 301-306.

Ribeiro, M. C. L. B., M. Petrere Jr. \& A. A. Juras. 1995. Ecological integrity and fisheries ecology of the AraguaiaTocantins River Basin, Brazil. Regulated Rivers: Research \& Management, 11: 325-350.

Ricklefs, R. E. 2006. Evolutionary diversification and the origin of the diversity-environment relationship. Ecology, 87(7, supplement): S3-S13.

Rodriguez, M. A. \& W. M. Lewis, Jr. 1997. Structure of fish assemblages along environmental gradients in floodplain lakes of the Orinoco River. Ecological Monographs, 67: 109128.

Schleuter, D., M. Daufresne, J. Veslot, N. W. H. Mason, C. Lanoiselée, S. Brosse, O. Beauchard \& C. Argillier. 2012. Geographic isolation and climate govern the functional diversity of native fish communities in European drainage basins. Global Ecology and Biogeography, 21: 1083-1095.

Schlosser, I. J. 1987. The role of predation in age- and sizerelated habitat use by stream fishes. Ecology, 68: 651-659.

Schlosser, I. J. 1990. Environmental variation, life history attributes, and community structure in stream fishes: implications for environmental management and assessment. Environmental Management, 14: 621-628.

Schlosser, I. J. 1991. Stream fish ecology: a landscape perspective. BioScience, 41: 704-712.

SIEG. 2014. Sistema Estadual de Estatística e Informações Geográficas de Goiás. Available in: http://www.sieg.go.gov. br/ (01/05/2014).

Sivasundar, A., E. Bermingham \& G. Ortí. 2001. Population structure and biogeography of migratory freshwater fishes (Prochilodus: Characiformes) in major South American rivers. Molecular Ecology, 10: 407-417.

Soulsby, C., A. F. Youngson, H. J. Moir \& I. A. Malcolm, 2001. Fine sediment influence on salmonid spawning habitat in a lowland agricultural stream: a preliminary assessment. The Science of the Total Environment, 265: 295-307.
Stewart, D. J., M. Ibarra \& R. Barriga-Salazar. 2002. Comparison of deep-river and adjacent sandy-beach fish assemblages in the Napo River Basin, Eastern Ecuador. Copeia, 2: 333-343

Súarez, Y. R., S. B. Valério, K. K. Tondato, L. Q. L. Ximenes \& T. R. A. Felipe. 2007. Determinantes ambientais da ocorrência de espécies de peixes em riachos de cabeceira da bacia do rio Ivinhema, alto rio Paraná. Acta Scientiarum Biological Sciences, 29: 145-150.

Suguio, K. \& J. J. Bigarella. 1990. Ambientes fluviais. 2. ed. Florianópolis, Editors da UFSC; Editora da UFPR. 183p.

Swift, C. C., C. R. Gilbert, S. A. Bortone, G. H. Burgess \& R. W. Yerger. 1986. Zoogeography of the freshwater fishes of the southeastern United States: Savannah River to Lake Pontchartrain. Pp. 213-265. In: Hocutt, C. H. \& E. O. Wiley (Eds.). The Zoogeography of North American freshwater fishes. New York, Wiley.

Tejerina-Garro, F. L. 2008. Biodiversidade e impactos ambientais no estado de Goiás: o meio aquático. Pp. 15-47. In: Rocha, C., F. L. Tejerina-Garro \& J. P. Pietrafesa (Orgs.). Cerrado, sociedade e meio ambiente: desenvolvimento sustentável em Goiás. Goiânia, Editora da UCG.

Tejerina-Garro, F. L., R. Fortin \& M. A. Rodríguez. 1998. Fish community structure in relation to environmental variation in floodplain lakes of the Araguaia River, Amazon Basin. Environmental Biology of Fishes, 51: 399-410.

Teresa, F. B. \& L. Casatti. 2012. Influence of forest cover and mesohabitat types on functional and taxonomic diversity of fish communities in Neotropical lowland streams. Ecology of Freshwater Fish, 21: 433-442.

Tockner, K., F. Malard \& J. V. Ward. 2000. An extension of the flood pulse concept. Hydrological Processes, 14: 2861-2883.

Vannote, R. L., G. W. Minshall, K. W. Cummings, J. R. Sedell \& C. E. Cushing. 1980. The river continuum concept. Canadian Journal of Fisheries and Aquatic Sciences, 37: 130-137.

Walters, D. M., D. S. Leigh \& A. B. Bearden. 2003. Urbanization, sedimentation, and the homogenization of fish assemblages in the Etowah River Basin, USA. Hydrobiologia, 494: 5-10.

Willis, S. C., K. O. Winemiller \& H. López-Fernandez. 2005. Habitat structural complexity and morphological diversity of fish assemblages in a Neotropical floodplain river. Oecologia, 142: 284-295.

Winemiller, K. O. 1989. Patterns of variation in life history among South American fishes in seasonal environments. Oecologia, 81: 225-241.

Winemiller, K. O. \& D. B. Jepsen. 1998. Effects of seasonality and fish movement on tropical river food webs. Journal of Fish Biology, 53: 267-296.

Submitted September 5, 2013

Accepted January 16, 2015 by Fabrício Teresa

Published June 30, 2015 
Table S1. Functional traits of species sampled in headwater streams of the Araguaia and Tocantins river basins.

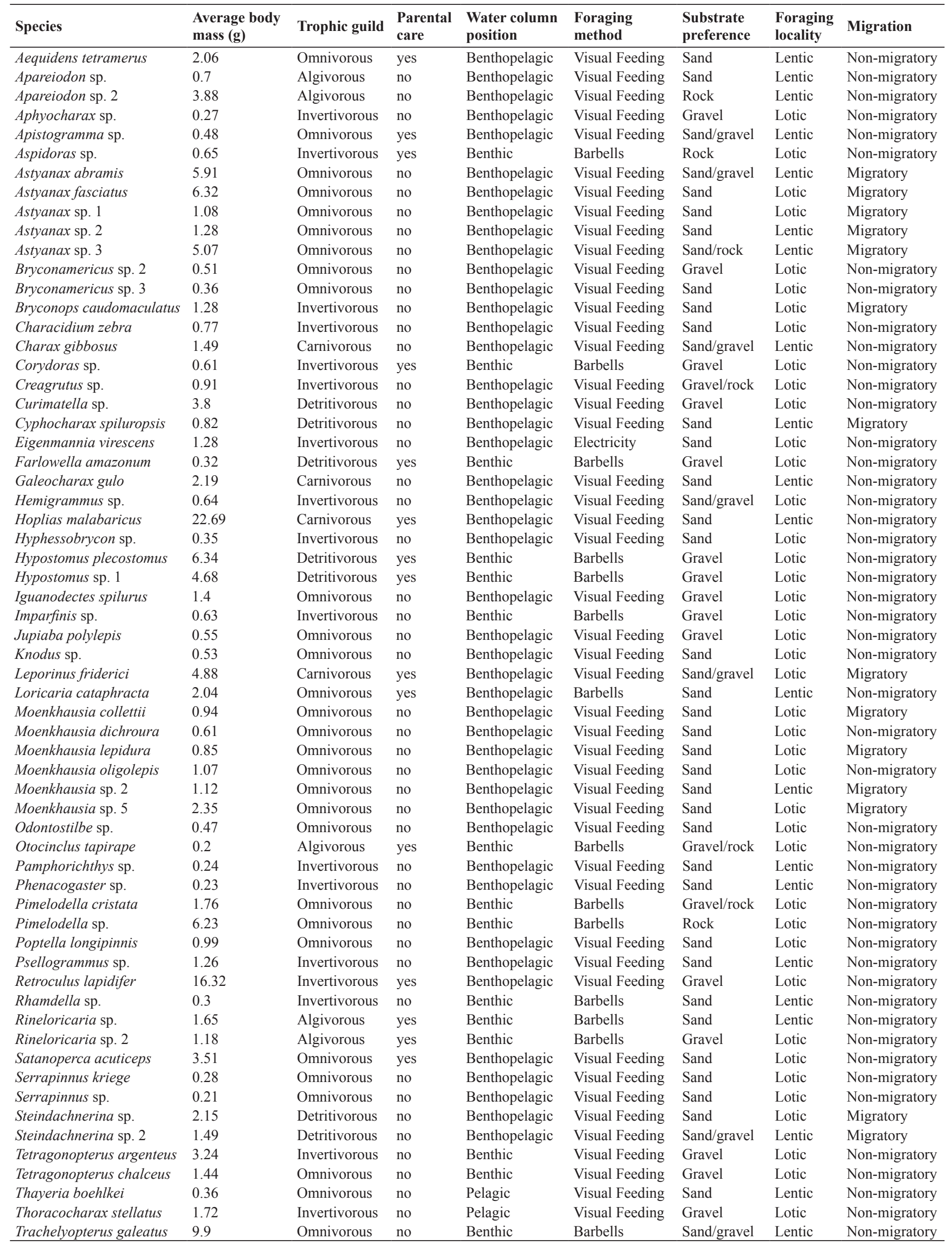

